\title{
Disruption of the microbial food web and inhibition of metazooplankton development in the presence of iron- and DOM-stimulated Baltic Sea cyanobacteria
}

\author{
Betina Kozlowsky-Suzuki ${ }^{1,2,6, *}$, Miina Karjalainen ${ }^{3}$, Marja Koski $^{4}$, Per Carlsson ${ }^{1,2}$, \\ Willem Stolte $^{1}$, Maija Balode ${ }^{5}$, Edna Granéli ${ }^{1}$ \\ ${ }^{1}$ Department of Biology and Environmental Science, University of Kalmar, 392-82 Kalmar, Sweden \\ ${ }^{2}$ Marine Biology, Campus Helsingborg, Lund University, Box 882, 251-08 Helsingborg, Sweden \\ ${ }^{3}$ Finnish Institute of Marine Research, Eric Palménin aukio 1, 00561 Helsinki, Finland \\ ${ }^{4}$ Danish Institute for Fisheries Research, Kavalergården 6, 2920 Charlottenlund, Denmark \\ ${ }^{5}$ Institute of Aquatic Ecology, University of Latvia, 19 Raina Boulevard, 1586 Riga, Latvia \\ ${ }^{6}$ Present address: Departamento de Ecologia e Recursos Marinhos, Universidade Federal do Estado do Rio de Janeiro \\ (UNIRIO), Av. Pasteur 458, Urca, 22290-040 Rio de Janeiro, Brazil
}

\begin{abstract}
Summer $\mathrm{N}_{2}$-fixing cyanobacterial blooms are a common feature in the Baltic Sea, and the occurrence of Nodularia spumigena toxic blooms is of particular concern. Cyanobacterial blooms can be favoured by certain conditions including high concentrations of dissolved organic matter, which may increase the availability of iron critical for $\mathrm{N}_{2}$ fixation. Cyanobacteria may negatively affect grazers because many species produce toxins and generally lack fatty acids essential for zooplankton reproduction. In this study we investigated the effect of riverine high-molecular weight dissolved organic matter (DOM-)/iron-stimulated cyanobacteria on the development of proto- and metazooplankton, and evaluated the role of DOM in stimulating the zooplankton part of the microbial food web. A plankton community was incubated in cylinders with either nitrate $\left(\mathrm{NO}_{3}\right)$ or DOM alone or combined with iron $(\mathrm{Fe})$ or zooplankton $>100 \mu \mathrm{m}(\mathrm{G})$. The development of proto- and metazooplankton was followed for $10 \mathrm{~d}$. Trophic relationships between metazooplankton taxa and their potential food items were assessed by ordination analysis and by feeding and reproduction bottle incubations with the calanoid copepod Acartia bifilosa. Contrary to our expectations, DOM did not stimulate the microbial food web, and proto- and metazooplankton developed similarly in all treatments until the middle of the experiment. However, by the end of the experiment, the biomass of proto- and metazooplankton as well as the biomass of diatoms and dinoflagellates was greatly depressed in all DOM and $\mathrm{NO}_{3} \mathrm{Fe}$ treatments. In these treatments, cyanobacterial and bacterial biomasses were highest leading up to phosphate depletion. Plankton development seemed to be bottom-up controlled and to be affected by extracellular compound(s) produced by the dominant cyanobacteria, possibly triggered by phosphate limitation. Diatoms, dinoflagellates, protozoans and metazooplankton were instead stimulated in the $\mathrm{NO}_{3}$ and $\mathrm{NO}_{3} \mathrm{G}$ treatments, where cyanobacterial biomass was low. Accordingly, A. bifilosa reproduction and survival were sustained in $\mathrm{NO}_{3}$ bottles. Deleterious effects of cyanobacteria on metazooplankton were diminished in $\mathrm{NO}_{3}$ and $\mathrm{NO}_{3} \mathrm{G}$ tanks where other food resources were available. Overall, the results suggest that increases in the input of DOM to the Baltic Sea can potentially stimulate cyanobacterial blooms that may disrupt the microbial food web and inhibit metazooplankton development.
\end{abstract}

KEY WORDS: Riverine high-molecular weight dissolved organic matter (DOM) · Iron · Microbial food web · Acartia bifilosa $\cdot$ Zooplankton · Cyanobacteria · Extracellular compounds 


\section{INTRODUCTION}

Summer cyanobacterial blooms, mostly dominated by the $\mathrm{N}_{2}$-fixing cyanobacteria Aphanizomenon flosaquae and Nodularia spumigena, are a common feature in the Baltic Sea. Of great health and environmental concern is the occurrence of hepatotoxic blooms of the latter species. In the Baltic Sea, cyanobacterial blooms are favoured by certain conditions such as $\mathrm{N}$ limitation, low N:P ratios, negligible grazing pressure and large amounts of dissolved organic matter (Howarth et al. 1988, Hagström et al. 2001).

Cyanobacteria may directly use compounds from the low-molecular weight fraction of dissolved organic matter (e.g. Balode et al. 1998), and their success may be facilitated by high concentrations of dissolved organic matter in 2 other ways. Dissolved organic matter might increase the availability of trace metals, such as molybdenum and iron, and through chelation may enable planktonic cyanobacterial $\mathrm{N}_{2}$ fixation (Howarth et al. 1988). Because dissolved organic matter can be assimilated by bacteria and thereby stimulate the microbial food web (Carlsson et al. 1995), which in turn sustains metazooplankton even in the absence of recent algal production (Daniel et al. 2005), high availability of dissolved organic matter might also lead to relaxation of grazing pressure on cyanobacteria. Thus, even if toxic filamentous cyanobacteria from the Baltic Sea can be consumed by calanoid copepods (Koski et al. 2002, Kozlowsky-Suzuki et al. 2003), dissolved organic matter-stimulated protists plus metazooplankton may collectively graze on smaller-sized and/or on more edible food particles and regenerate nutrients that contribute to cyanobacteria dominance.

In the Baltic Sea, at the onset of summer cyanobacterial blooms, riverine loads of dissolved organic nutrients can be as important as the input of inorganic nutrients (Stepanauskas et al. 2002). This coincides with the increase of heterotrophic bacterial production and the dominance of small $(<10 \mu \mathrm{m})$ phytoplankton, which in turn stimulates the highest levels of protozoan predation in the annual cycle (Hagström et al. 2001). Under such conditions, even if most of the primary production is lost through respiration in the microbial food web, protozoans may become the main trophic link to metazooplankton. In addition, cyanobacteria may negatively affect grazers. For instance, they generally lack polyunsaturated fatty acids such as 20:5 13 and 22:6 $\omega 3$ (Brett \& Müller-Navarra 1997) essential for reproduction in crustaceans, and many produce potent toxins that impair direct grazers (Lampert 1987). In spite of this, grazers may consume toxic cyanobacteria in the Baltic Sea (Koski et al. 2002, Kozlowsky-Suzuki et al. 2003) with the deleterious effects possibly being diminished by the presence of other food sources (Reinikainen et al. 1994).
This study is part of a mesocosms experiment (Stolte et al. 2006) in which the central hypothesis was that riverine high-molecular weight dissolved organic matter (referred to as DOM herein) would stimulate the growth of $\mathrm{N}_{2}$-fixing cyanobacteria (1) directly, by increasing the availability of iron and (2) indirectly, by stimulating a heterotrophic link from bacteria to metazooplankton via heterotrophic flagellates and ciliates. Thus, because cyanobacterial growth and $\mathrm{N}_{2}$ fixation can be limited by iron in the Baltic Sea (Stal et al. 1999), inputs of riverine organic matter likely stimulate the development of these microorganisms. In addition, by stimulating the microbial food web and metazooplankton development, extra inputs of riverine DOM may release cyanobacteria from strong grazing pressure.

Stolte et al. (2006) reported the development of bacteria and phytoplankton, especially cyanobacteria, following manipulations of DOM/nutrients and grazers. In the present study we evaluated the role of DOM in stimulating the zooplankton part of the microbial food web and the effect of DOM-/ironstimulated cyanobacteria on the development of proto- and metazooplankton. We expected that DOM would stimulate the microbial food web, which would provide an additional food resource and thus help to counterbalance the possible negative effects of toxic and/or low nutritional quality cyanobacteria on potential grazers (metazooplankton). By using ordination analysis we further assessed the relationships between the metazooplankton taxa and their major food types, and in turn related these to feeding and reproduction of the calanoid copepod Acartia bifilosa in bottle incubations.

\section{MATERIALS AND METHODS}

Mesocosm experiment set-up, sampling and analyses. A short description of the experimental set-up and procedures is given below; for further information see Stolte et al. (2006). A summer plankton community $(<100 \mu \mathrm{m})$ collected from the Baltic Proper $\left(56^{\circ} 55^{\prime} 85^{\prime \prime} \mathrm{N}, 17^{\circ} 01^{\prime} 82^{\prime \prime} \mathrm{E}\right)$ was incubated in triplicate in polyethylene cylinders $(300 \mathrm{l})$ with either nitrate $\left(\mathrm{NO}_{3}\right)$ or DOM (riverine $>1 \mathrm{kDa}$ ) alone or in combination with iron $\left(\mathrm{NO}_{3} \mathrm{Fe}\right.$ and DOMFe) or zooplankton $>100 \mu \mathrm{m}\left(\mathrm{NO}_{3} \mathrm{G}\right.$ and $\left.\mathrm{DOMG}\right)$. Nutrients were added daily as follows: nitrogen sources $\left(\mathrm{NO}_{3}{ }^{-}\right.$or DOM): $0.1 \mu \mathrm{M}_{i} \mathrm{PO}_{4}{ }^{3-}: 0.2 \mu \mathrm{M}$; and $\mathrm{FeCl}_{2}: 0.1 \mu \mathrm{M}$.

Zooplankton samples were taken with a $100 \mu \mathrm{m}$ net by vertical hauls ( $20 \mathrm{~m}$ to the surface) at the same time that water for the mesocosm experiments was collected. In the laboratory, the zooplankton $>100 \mu \mathrm{m}$ size fraction was added (simultaneously with the first nutri- 
ent addition; see above) to some of the cylinders $\left(\mathrm{NO}_{3} \mathrm{G}\right.$ and DOMG) in the same numbers as observed in situ. All cylinders were placed at $18^{\circ} \mathrm{C}$ and exposed to $250 \mu \mathrm{mol}$ photons $\mathrm{m}^{-2} \mathrm{~s}^{-1}$ in an 18:6 h light:dark cycle.

Sampling in the cylinders was carried out after careful mixing of the water column. Samples for biological analyses were collected as follows: phytoplankton at Days $0,3,5,7,10$; nanoflagellates every second day from initial sampling (Day 0) onwards; and ciliates at Days 0, 5, 7 and 10. Metazooplankton samples from the pre-screened cylinders were taken at Days 5 and 10, while those from the cylinders containing grazers were collected at Days 0, 4 and 10.

Samples $(250 \mathrm{ml})$ for phytoplankton and ciliates analyses were fixed with acid Lugol's solution. Phytoplankton samples were settled in sedimentation chambers using the Utermöhl (1958) method and analysed under an inverted microscope (DM IL, LEICA). The biomass (wet wt) of each phytoplankton taxon was calculated from cell biovolume according to the Baltic Marine Biologists' recommendations (Edler 1979). At least 20 cells were measured in order to estimate the cell volume. Ciliates were counted in $10 \mathrm{ml}$ sedimentation chambers. Samples $(20 \mathrm{ml})$ for the analysis of nanoflagellates were fixed with $10 \mu \mathrm{l}$ alkaline Lugol's solution, immediately followed by the addition of 0.4 to $0.5 \mathrm{ml}$ of $1 \%$ borate-buffered formalin and $20 \mu \mathrm{l}$ of $3 \%$ sodiumthiosulphate (to bleach the lugol) (Sherr \& Sherr 1993). An aliquot was then stained with DAPI (final concentration $0.1 \mu \mathrm{g} \mathrm{ml}^{-1}$ ) and filtered through $0.8 \mu \mathrm{m}$ black polycarbonate filters, which were then mounted on microscope glass slides before cells were enumerated by microscopy (Sherr et al. 1993). For the metazooplankton analysis, 51 aliquots from each cylinder were concentrated using a $100 \mu \mathrm{m}$ net and preserved in $4 \%$ formaldehyde. Entire samples were counted in sedimentation chambers. The biomass of each metazooplankton taxon was calculated using individual wet wt determinations according to the Baltic Marine Biologists' recommendations (Hernroth 1985).

Bottle incubations: feeding and reproduction experiments. Acartia bifilosa feeding and egg production experiments were conducted simultaneously with the mesocosm experiment. Feeding experiments were run on 2 occasions (Expts 1 and 2, corresponding to Days 0 and 4 of the mesocosm experiment), using the treatments that received $\mathrm{NO}_{3}$ and DOM. Reproduction experiments were conducted on 3 occasions (Expts 1, 2 and 3, the latter corresponding to Day 10 of the mesocosm experiment), using water from the $\mathrm{NO}_{3}, \mathrm{NO}_{3} \mathrm{Fe}$, DOM and DOMFe tanks. Acartia bifilosa adult females were collected at sea on the day preceding each of these experiments.
Females were individually isolated and kept overnight in seawater filtered using Whatman GF/C filters. After the starvation period, ca. 20 to 25 females per bottle were incubated in triplicate 1.31 plastic bottles containing water from the different mesocosm treatments. Control bottles (without copepods) were also incubated in triplicate. All bottles were placed on a plankton wheel under the same temperature and light conditions as the cylinders.

Feeding experiments lasted $24 \mathrm{~h}$, after which the females were gently collected on $100 \mu \mathrm{m}$ nets and reincubated with water from the same mesocosm treatments for 2 consecutive $24 \mathrm{~h}$ periods, in order to determine the egg production rate (EPR). After each $24 \mathrm{~h}$ period, females and eggs were gently collected on 100 and $25 \mu \mathrm{m}$ nets, respectively, and counted. EPR was corrected for the number of eggs in the natural community water at Day 0 and for the potential number of eggs produced by the few adult females that subsequently appeared in the tanks. A number of the eggs (usually 30, but in some cases all) were placed in Petri dishes with filtered seawater in order to estimate egghatching success $(\mathrm{EH})$. These Petri dishes were placed under the same temperature and light conditions as the cylinders for $48 \mathrm{~h}$. EH was only estimated from the eggs produced during the first $24 \mathrm{~h}$ EPR incubation.

Samples (50 to $100 \mathrm{ml}$ ) for the enumeration of phytoplankton and ciliates were taken at the start $(0 \mathrm{~h})$ and completion ( $24 \mathrm{~h}$ ) of the feeding experiment and preserved in acid Lugol's solution. Entire samples were counted in sedimentation chambers of different volumes, depending on the density of the filaments/cells, and at least 20 cells of the initial samples were measured in order to estimate the cell volume. In the case of filamentous cyanobacteria, cell concentration was estimated by dividing the measured length (in $\mu \mathrm{m}$ ) of individual filaments by the average length of a single cell.

Clearance and ingestion rates were estimated according to Frost (1972). Ingestion rates of the different food types were converted to carbon by employing a conversion factor of $0.11 \mathrm{pg} \mu^{3}$ for phytoplankton and ciliates, and $0.13 \mathrm{pg} \mathrm{m}^{3}$ for armoured dinoflagellates (Edler 1979). Total ingestion rates (TIR) of the 3 major groups (cyanobacteria, ciliates and dinoflagellates) were calculated as the sum of the ingestion rates of all food types in the respective group. Food selection was determined by the selectivity coefficient $\alpha$, which relates the ingestion rates of the different food types to their availability (Chesson 1978). No selection occurs when $\alpha=\mathrm{m}^{-1}$ (where $\mathrm{m}=$ no. of food types available) and food items are fed upon in the same proportion as their availability; in contrast, if $\alpha>$ $\mathrm{m}^{-1}$ then selection is positive, and when $\alpha<\mathrm{m}^{-1}$ then selection is negative. 
Data analysis. All data were tested for homogeneity of variances and normality. If those assumptions were not met, the data were log- or square roottransformed. The effect of the different treatments on the abundance of ciliates and metazooplankton was tested with 1-way multivariate analysis of variance (MANOVA), where treatments were independent variables and the abundance estimated on each sampling day was the dependent variable. In case of a significant response, 1-way ANOVA followed by Tukey's Honestly Significant Difference (HSD) a posteriori test was used for the different days. Friedman ANOVA was used to test differences in Acartia bifilosa clearance and ingestion rates on different food items within each treatment; differences between treatments were tested with $t$-tests for independent samples. Two-way MANOVAs were used to test the effect of nutrient manipulation and experimental time on the following dependent variables: ingestion rates of the 3 major groups (cyanobacteria, ciliates and dinoflagellates) and survival at 24 and 72 h. If significant results were detected, 2-way ANOVAs followed by Tukey's HSD test were used, and $t$-tests for dependent samples were used to test whether EPR (24 and $48 \mathrm{~h}$ ) and survival (24 and $72 \mathrm{~h}$ ) at consecutive incubation times differed for each treatment and experiment. The effect of nutrient manipulation and experiment time on TIR, EPR and $\mathrm{EH}$ was tested with 2-way ANOVA. Relationships between cyanobacterial biomass and EPR, EH and survival were assessed with the Spearman rank correlation, and $t$-tests followed by the sequential Bonferroni method (applied to adjust $\alpha$-values) were used to assess whether the selectivity coefficients of the different food types were significantly different from the non-selection value.

The development of the plankton community in the different treatments and the relationships between metazooplankton taxa and their potential food items (entered as environmental variables) were assessed by Redundancy Analysis (RDA). The average biomass of each metazooplankton taxa and the main food items (cyanobacteria, diatoms, dinoflagellates, ciliates $<20 \mu \mathrm{m}$ and ciliates $>20 \mu \mathrm{m}$ ) in each treatment on Days 5 and 10 were used in the analysis. The biomasses of the different food items were square roottransformed before entry into the analysis. The significance of the RDA axes was tested by running 1999 unrestricted permutations in the Monte Carlo test. Because no samples for metazooplankton analysis were taken from the pre-screened tanks on Day 0, the initial sampling was not used in the analysis; furthermore, major responses to the experimental manipulations only began to diverge at the middle of the experiment (Day 5) and continued to do so until the end.

\section{RESULTS}

\section{Mesocosm experiment}

Protozooplankton development

The abundance of $<5 \mu \mathrm{m}$ nanoflagellates (which comprised at least $60 \%$ heterotrophic flagellates) increased in all treatments until Day 8, after which it decreased considerably (DOM treatments) or stabilised $\left(\mathrm{NO}_{3}\right.$ treatments) (Fig. 1A). Numbers of small $(<20 \mu \mathrm{m})$ and large $(>20 \mu \mathrm{m})$ ciliates increased from the start to the middle (Day 5) of the experiment (Fig. 1B,C). Thereafter, small ciliates decreased in numbers, whereas larger ciliates continued to increase until the end of the experiment by which time large ciliates were dominated by Euplotes sp.

Both small and large ciliates were affected by nutrient manipulation (1-way MANOVA; p < 0.001), with the addition of grazers having no clear effect (Tukey's HSD; $\mathrm{p}>0.05)$. Ciliates reached higher numbers in the treatments receiving $\mathrm{NO}_{3}$, contrasting with the lower numbers in the DOM treatments. However, complete

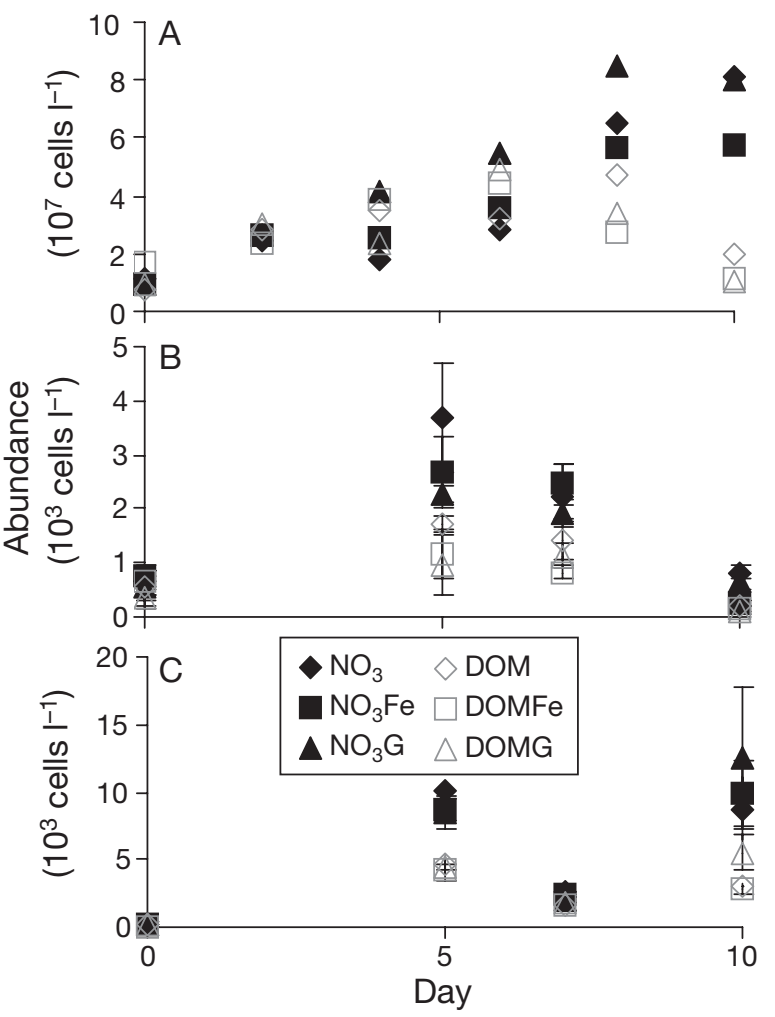

Fig. 1. Protozooplankton abundance in different treatments: (A) nanoflagellates $<5 \mu \mathrm{m}$, (B) small ciliates $(<20 \mu \mathrm{m})$ and (C) large ciliates $(>20 \mu \mathrm{m})$. Nitrate $\left(\mathrm{NO}_{3}\right)$ and DOM were added to mesocosms alone or in combination with iron $\left(\mathrm{NO}_{3} \mathrm{Fe}\right.$ and DOMFe, respectively) or zooplankton $>100 \mu \mathrm{m}\left(\mathrm{NO}_{3} \mathrm{G}\right.$ and DOMG, respectively). Data are mean \pm SD (NB: SD not given in A). DOM: riverine hight-molecular weight dissolved organic matter 
separation of these 2 major treatments was only significant (Tukey's HSD; p < 0.05) on Day 5 for large ciliates, when their abundance was on average 2-fold higher in all $\mathrm{NO}_{3}$ treatments (Fig. 1C).

\section{Metazooplankton development in cylinders with added grazers}

The number of grazers $(>100 \mu \mathrm{m})$ in the tanks receiving $\mathrm{NO}_{3} \mathrm{G}$ (mean $\pm \mathrm{SD}: 18 \pm 6$ ind. $\left.\mathrm{l}^{-1}\right)$ and DOMG $(16 \pm$ 9 ind. $\mathrm{l}^{-1}$ ) at the start of the experiment was in the same range as the in situ zooplankton abundance $(17 \pm 1$ ind. $\mathrm{l}^{-1}$ ). The total metazooplankton abundance ranged from 5 to 268 ind. $1^{-1}$ throughout the experiment and was affected by the nutrient manipulations (Fig. 2A,B; 1 -way MANOVA; $\mathrm{p}<0.05$ ). From the start (Day 0) to the middle (Day 4) of the experiment, metazooplankton community structure developed similarly in both treatments. However, by the end of the experiment (Day 10), the abundance of most taxa, especially copepods (nauplii, copepodites and adults), had decreased considerably in the DOMG treatment (Fig. 2A,B). At that time, total zooplankton abundance was significantly lower in the DOMG treatment (Tukey's HSD; $\mathrm{p}<0.01$ ) and the community was also less diverse

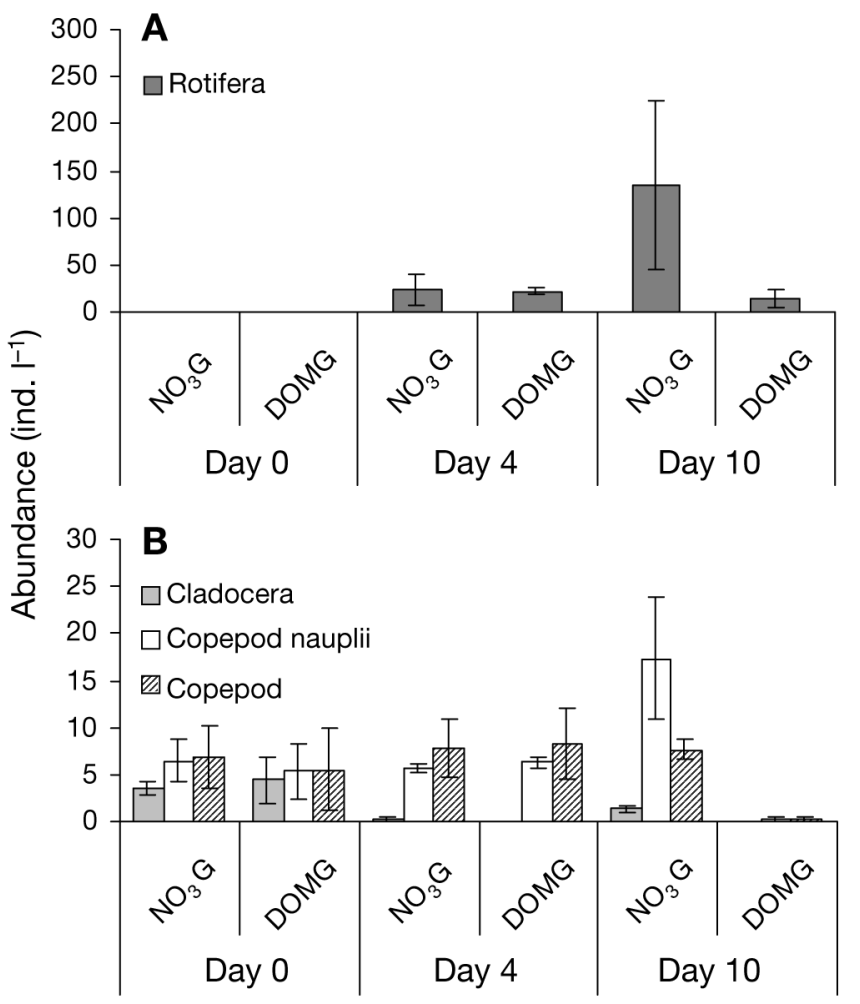

(Synchaeta spp. comprised $>90 \%$ of the total metazooplankton abundance) than that in the $\mathrm{NO}_{3} \mathrm{G}$ tanks (Fig. 2A,B).

Cladocerans and copepods dominated at the start of the experiment (Fig. 2B). Cladocerans were represented by Evadne nordmanni (average abundance $85 \%)$, Pleopsis polyphemoides (14\%) and Bosmina longispina maritima (<1\%), whereas nauplii $(65 \%$ of Acartia bifilosa), copepodites (79\% of A. bifilosa) and adults of the calanoids $A$. bifilosa, Centropages hamatus and Temora longicornis represented the copepods.

Numbers of Evadne nordmanni and nauplii, copepodites and adults of Centropages hamatus and Temora longicornis all declined over the course of the experiment, and some were even absent from both treatments $\left(\mathrm{NO}_{3} \mathrm{G}\right.$ and DOMG) on the last day. The contribution of rotifers (Synchaeta spp.) progressively increased and became considerably higher in the $\mathrm{NO}_{3} \mathrm{G}$ treatment on the last day of experiment, whereas the population in the DOMG tanks was unable to develop after Day 4 (Fig. 2A). By the end of the experiment, Pleopsis polyphemoides and Bosmina longispina maritima numbers increased slightly in the $\mathrm{NO}_{3} \mathrm{G}$ treatment, whereas the abundance of nauplii and adults of Acartia bifilosa (Figs. 2B \& 3) were significantly higher (Tukey's HSD; $\mathrm{p}<0.01$ ) than in the DOMG tanks.
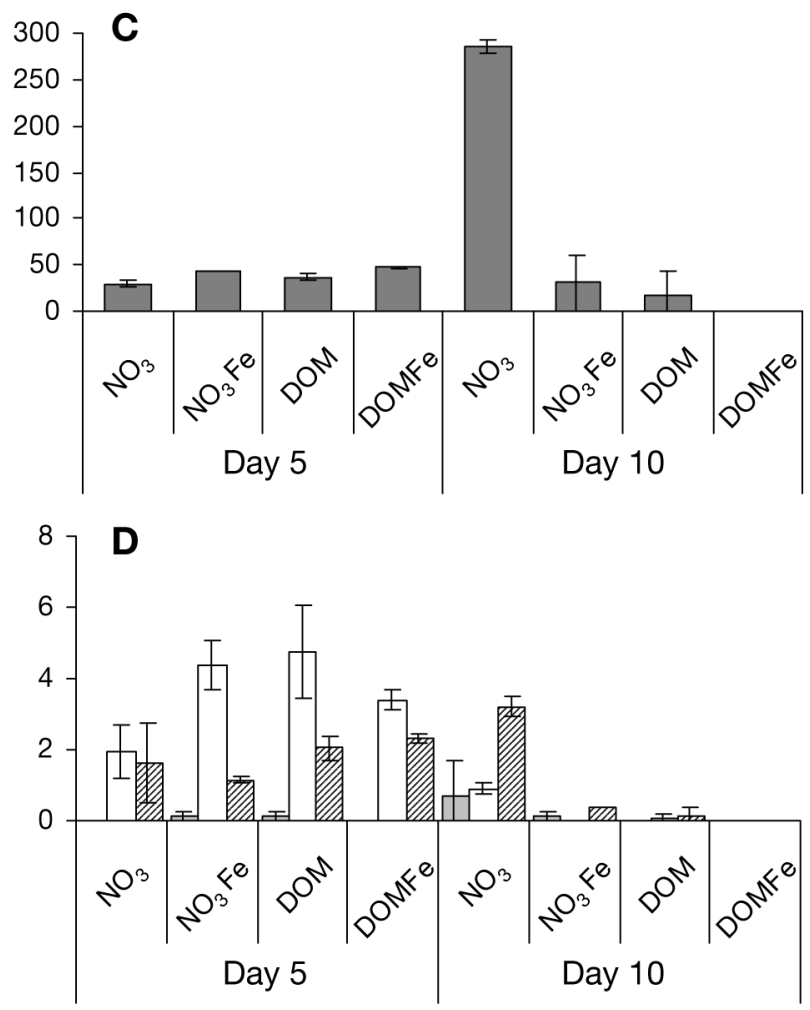

Fig. 2. Metazooplankton abundance (mean $\pm \mathrm{SD}$ ). Abundance of (A) Rotifera and (B) Cladocera, copepod nauplii and copepods in tanks with >100 $\mu \mathrm{m}$ grazers; abundance of (C) Rotifera and (D) Cladocera, copepod nauplii and copepods in pre-screened tanks. Abbreviations as in Fig. 1 
Metazooplankton development in pre-screened cylinders

After $5 \mathrm{~d}$ of experiment, some metazooplankton taxa (i.e. Synchaeta spp. and copepod nauplii) in the prescreened $(<100 \mu \mathrm{m})$ treatments had reached numbers comparable with those observed in the tanks where grazers were added (Figs. 2C,D \& 3). The community in the $\mathrm{NO}_{3}$ treatment tended to develop similarly to those in the $\mathrm{NO}_{3} \mathrm{G}$ tanks, even if a population of adult copepods was not yet established (Fig. 3). By the end of the experiment, the abundance of most taxa had decreased markedly in the $\mathrm{NO}_{3} \mathrm{Fe}$, DOM and DOMFe treatments and exhibited similar trends to that observed for the DOMG treatment (Fig. 2). At that time, the abundances of the total metazooplankton and Synchaeta spp. were significantly lower (Tukey's HSD; $\mathrm{p}<0.01$ ) in the $\mathrm{NO}_{3} \mathrm{Fe}$, DOM and DOMFe treatments than in the $\mathrm{NO}_{3}$ tanks.

Plankton development and relationships between metazooplankton and food items

The development of the plankton community following experimental manipulations (addition of nutrient

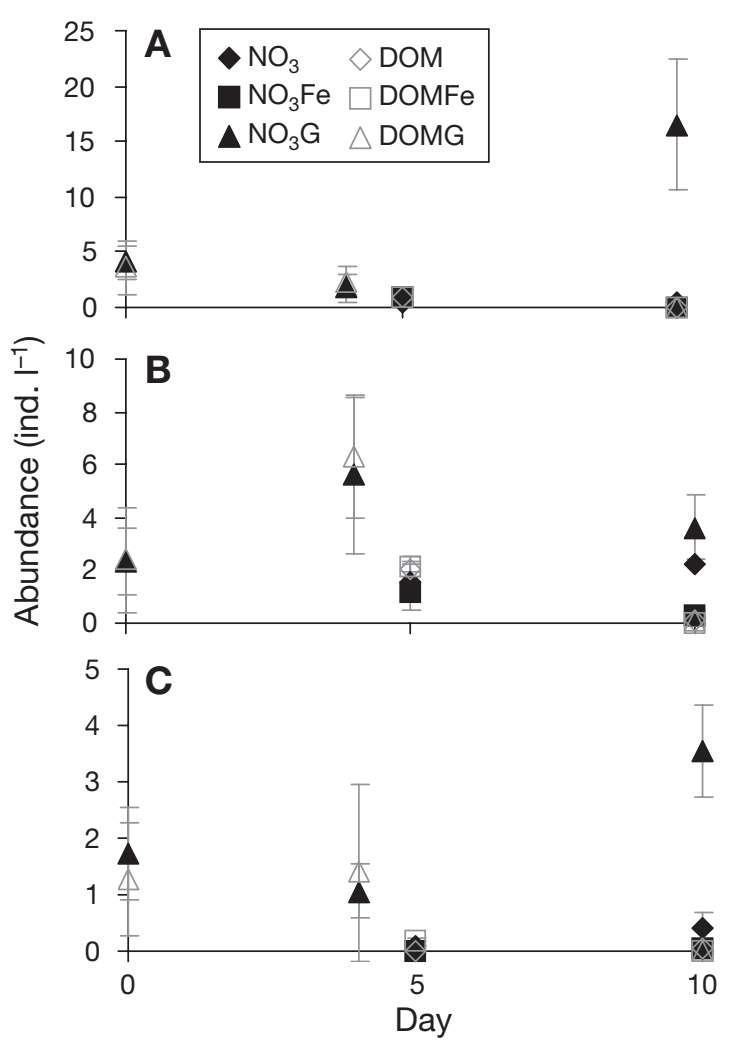

Fig. 3. Acartia bifilosa. Mean abundance $( \pm \mathrm{SD})$ of $(\mathrm{A})$ nauplii, (B) copepodites and (C) adults in different treatments. Abbreviations as in Fig. 1 and grazers) and the relationships between metazooplankton and potential food items are summarised in the ordination diagram (Fig. 4). The proximity of the different treatments (numbers 1 to 6 ) in the ordination diagram by the middle of the experiment (Day 5) indicates that the plankton structure and development were fairly similar in the different tanks at this time. However, by Day 10, plankton responses in the different treatments had diverged considerably.

The first 2 axes of Fig. 4 have eigenvalues of 0.67 and 0.07 , and explain $75 \%$ of the metazooplankton distribution and $97 \%$ of the species-environment (metazooplankton-food item) relationship. Both the first and all canonical axes together were significant $(p=0.02)$ in the Monte Carlo test. The correlations

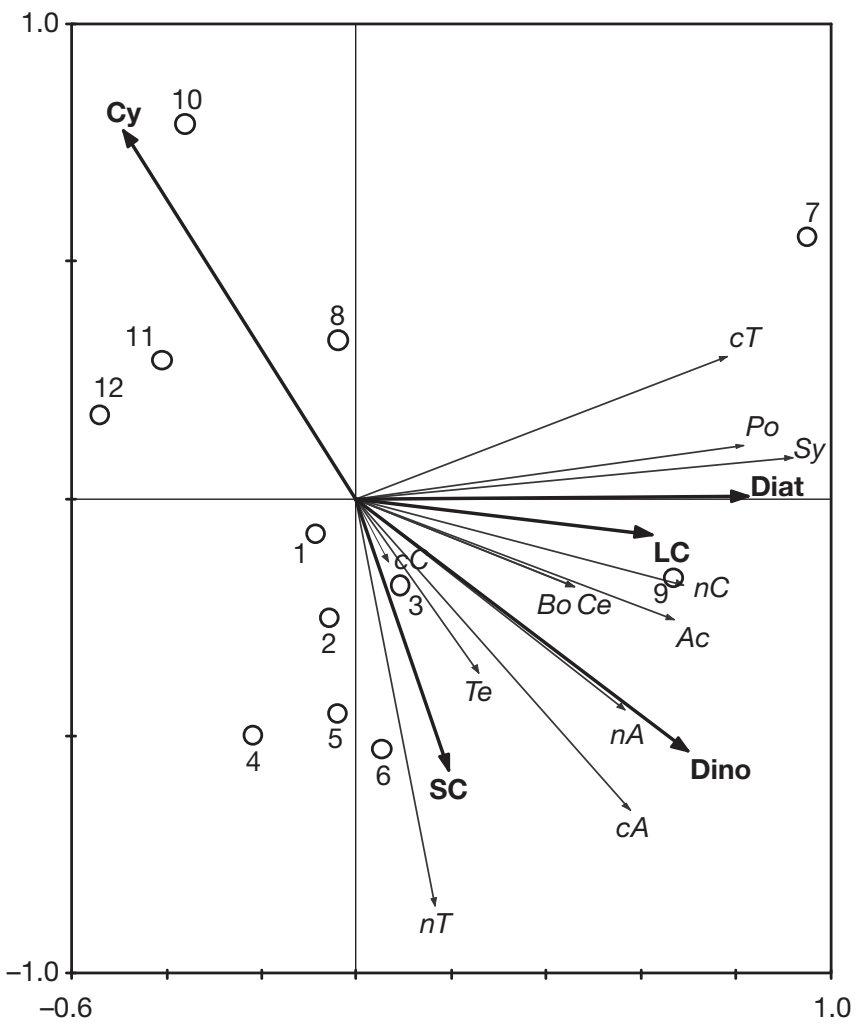

Fig. 4. Ordination diagram showing the first (horizontal) and second (vertical) axes of Redundancy Analysis (RDA). Numbers represent different treatments on Day $5\left(1=\mathrm{NO}_{3 i} 2=\right.$ $\left.\mathrm{NO}_{3} \mathrm{Fe}_{3} 3=\mathrm{NO}_{3} \mathrm{G} ; 4=\mathrm{DOM} ; 5=\mathrm{DOMFe} ; 6=\mathrm{DOMG}\right)$ and Day $10\left(7=\mathrm{NO}_{3} ; 8=\mathrm{NO}_{3} \mathrm{Fe}_{i} 9=\mathrm{NO}_{3} \mathrm{G} ; 10=\mathrm{DOM}_{;} 11=\right.$ DOMFe; 12 = DOMG) (Abbreviations as in Fig. 1). Potential food items (environmental variables) represented by bold arrows: $\mathrm{Cy}=$ cyanobacteria; Diat $=$ diatoms; $\mathrm{SC}=$ ciliates $<20$ $\mu \mathrm{m} ; \mathrm{LC}=$ ciliates $>20 \mu \mathrm{m} ;$ Dino $=$ dinoflagellates. Metazooplankton taxa represented by thin arrows: $n T, c T \& T e=$ nauplii, copepodites and adults of Temora longicornis; $n C, c C \&$ $\mathrm{Ce}=$ nauplii, copepodites and adults of Centropages hamatus; $n A, c A \& A c=$ nauplii, copepodites and adults of Acartia bifilosa; $P o=$ Pleopsis polyphemoides; $S y=$ Synchaeta spp.; $B o=$ Bosmina longispina maritima 
between the ordination axes and food types (environmental variables) indicated that the first axis was related to the availability of diatoms, dinoflagellates and large ciliates, whereas the second axis was mainly related to the development of cyanobacteria. The first axis alone explained $87 \%$ of variation in the metazooplankton-food items relation, whereas the second axis accounted for only $10 \%$ of this variation. This means that most metazooplankton biomass was associated with the more diverse plankton community (represented by the first axis), which by the end of the experiment (Day 10) had developed in the $\mathrm{NO}_{3}$ and $\mathrm{NO}_{3} \mathrm{G}$ tanks (numbers 7 and 9). In those treatments, even if cyanobacteria became the dominant food type, the importance of the other food items was as great or had become greater since the start of the experiment. At the same time, cyanobacteria biomass had considerably increased (Stolte et al. 2006) in all DOM treatments in addition to that receiving $\mathrm{NO}_{3} \mathrm{Fe}$ (numbers 8, 10, 11 and 12); in contrast, the biomass of all the other food types and metazooplankton was generally much lower.
$33 \mathrm{ng} \mathrm{C}$ female ${ }^{-1} \mathrm{~h}^{-1}$ ) irrespective of treatment. The ingestion rate of dinoflagellates ranged from 4.7 to 8.7 ng C female $\mathrm{e}^{-1} \mathrm{~h}^{-1}$ and was neither affected by nutrient manipulation nor did it differ between experiments (2-way ANOVA; $\mathrm{p}>0.05)$.

Clearance and ingestion rates of the different food items were highly variable and ranged from negative values to $5.8 \mathrm{ml}$ female $^{-1} \mathrm{~h}^{-1}$ and $55 \mathrm{ng} \mathrm{C}$ female $^{-1}$ $h^{-1}$, respectively (Table 1 ), and did not differ significantly between treatments and experiments. However, in Expt 1, large ciliates $(>20 \mu \mathrm{m})$ were the most ingested food item (up to $12 \mathrm{ng} \mathrm{C}$ female $\mathrm{e}^{-1} \mathrm{~h}^{-1}$ ) in both treatments. In Expt 2, large ciliates were still the most ingested food item in the $\mathrm{NO}_{3}$ treatment (55 ng $\mathrm{C}$ female $\mathrm{f}^{-1} \mathrm{~h}^{-1}$ ), followed by Anabaena inaequalis (29 ng $\mathrm{C}$ female $\mathrm{e}^{-1} \mathrm{~h}^{-1}$ ). Although the ingestion rate of $A$. inaequalis in the DOM treatment was highly variable, this cyanobacterium was always fed upon to some extent (19 ng $\mathrm{C}$ female $\mathrm{f}^{-1} \mathrm{~h}^{-1}$ ). Acartia bifilosa fed non-selectively: the selectivity coefficient for all food types did not differ statistically from the non-selection value (Fig. 5).

\section{Bottle incubations}

\section{Feeding rates and food selectivity}

Acartia bifilosa TIR ranged from 28 to $95 \mathrm{ng} \mathrm{C}$ female ${ }^{-1} \mathrm{~h}^{-1}$ in the $\mathrm{NO}_{3}$ treatment, and from 29 to $34 \mathrm{ng} \mathrm{C}$ female ${ }^{-1}$ $\mathrm{h}^{-1}$ in the DOM treatment (Table 1 ). This variable increased from Expt 1 to Expt 2 (performed on Days 0 and 4 respectively; 2-way ANOVA; p < 0.05) but did not differ between treatments (2-way ANOVA; $\mathrm{p}>0.05$ ).

When the ingestion rates of the different food items were combined for taxonomic groups (cyanobacteria, ciliates and dinoflagellates) they differed between treatments (2-way MANOVA; $\mathrm{p}<0.05)$. The interaction between treatment and experiment was also significant (2-way MANOVA; $\mathrm{p}<0.05)$. In Expt 1, ciliates were the food type ingested most by Acartia bifilosa (13 ng C female ${ }^{-1} \mathrm{~h}^{-1}$ ) irrespective of treatment; in contrast, in Expt 2, ciliates were ingested at higher rates (57 $\mathrm{ng} \mathrm{C}$ female ${ }^{-1} h^{-1}$ ) in the $\mathrm{NO}_{3}$ treatment (2-way ANOVA; $\mathrm{p}<0.05$, Tukey's HSD; $\mathrm{p}<0.01)$. The ingestion rate of cyanobacteria was higher in Expt 2 (2-way ANOVA, Tukey's HSD; $\mathrm{p}<0.05$; up to
Table 1. Acartia bifilosa. Mean (SD) clearance $\left(\mathrm{ml}\right.$ female $\left.{ }^{-1} \mathrm{~h}^{-1}\right)$ and ingestion rate (IR, ng C female ${ }^{-1} \mathrm{~h}^{-1}$ ) of food items cyanobacteria, ciliates and dinoflagellates and total ingestion rates (TIR) in $\mathrm{NO}_{3}$ and DOM treatments during Expts 1

(Days 0 to 1 ) and 2 (Days 4 to 5). For treatment abbreviations see Fig. 1

\begin{tabular}{|c|c|c|c|c|}
\hline & \multicolumn{2}{|c|}{ Clearance rate } & \multicolumn{2}{|c|}{ Ingestion rate } \\
\hline & $\mathrm{NO}_{3}$ & DOM & $\mathrm{NO}_{3}$ & DOM \\
\hline \multicolumn{5}{|l|}{ Expt 1} \\
\hline Pseudoanabaena sp. & $0.6(1.9)$ & $0.4(2.1)$ & $2.1(3.8)$ & $1.1(4.6)$ \\
\hline Aphanizomenon flos-aquae & $1.5(3.9)$ & $5.4(2.9)$ & $4.4(9.3)$ & $5.5(1.8)$ \\
\hline IR cyanobacteria & & & $7.8(9.2)$ & $7.6(5.4)$ \\
\hline Ciliates $<20 \mu \mathrm{m}$ & $1.4(1.8)$ & $1.5(1.7)$ & $1.2(1)$ & $1.1(1.1)$ \\
\hline Ciliates $>20 \mu \mathrm{m}$ & $5.8(5.4)$ & $3.1(2.8)$ & $12(4.2)$ & $11(7.6)$ \\
\hline IR ciliates & & & $13(4.5)$ & $12(8.8)$ \\
\hline Gymnodinium spp. $<20 \mu \mathrm{m}$ & $4.0(3.8)$ & $2.7(1.7)$ & $2.1(1.1)$ & $2.0(1.2)$ \\
\hline Gymnodinium spp. $>20 \mu \mathrm{m}$ & $5.8(1.9)$ & $3.1(2.2)$ & $2.2(0.3)$ & $1.9(1.3)$ \\
\hline Peridinales < $20 \mu \mathrm{m}$ & $1.3(3.4)$ & $2.3(1.7)$ & $0.6(0.9)$ & $1.3(0.7)$ \\
\hline Dinophysis acuminata & $0.3(1.1)$ & $0.6(0.9)$ & $1.5(4.4)$ & $3.1(3.8)$ \\
\hline IR dinoflagellates & & & $7.5(3.7)$ & $8.7(3.7)$ \\
\hline TIR & & & $28(9)$ & $29(9)$ \\
\hline \multicolumn{5}{|l|}{ Expt 2} \\
\hline Anabaena inaequalis & $1.8(0.4)$ & $1.1(1.8)$ & $29(8)$ & $19(27)$ \\
\hline Pseudoanabaena sp. & $0.5(0.6)$ & $0.4(0.5)$ & $1.6(1.5)$ & $2.2(2.4)$ \\
\hline Nodularia spumigena & $-0.2(0.9)$ & $-0.2(3)$ & $-0.2(5)$ & $-5.6(13.6)$ \\
\hline IR cyanobacteria & & & $33(8)$ & $25(21)$ \\
\hline Ciliates < $20 \mu \mathrm{m}$ & $0.2(1.5)$ & $-3(1.6)$ & $1.3(2.9)$ & $-1.9(1)$ \\
\hline Ciliates > $20 \mu \mathrm{m}$ & $2.3(1.1)$ & $0.1(0.8)$ & $55(27)$ & $1.6(10.5)$ \\
\hline IR ciliates & & & $57(27)$ & $4.5(7.8)$ \\
\hline Gymnodinium spp. $<20 \mu \mathrm{m}$ & $3.2(2)$ & $0.6(0.6)$ & $1(0.8)$ & $0.2(0.2)$ \\
\hline Peridinales $>20 \mu \mathrm{m}$ & $1.3(1.4)$ & $0.3(2)$ & $2.7(3)$ & $0.6(3)$ \\
\hline Dinophysis acuminata & $0.02(1)$ & $0.5(1.3)$ & $0.4(3.6)$ & $2.1(5.1)$ \\
\hline IR dinoflagellates & & & $5.1(4.7)$ & $4.7(5.9)$ \\
\hline TIR & & & $95(38)$ & $34(35)$ \\
\hline
\end{tabular}



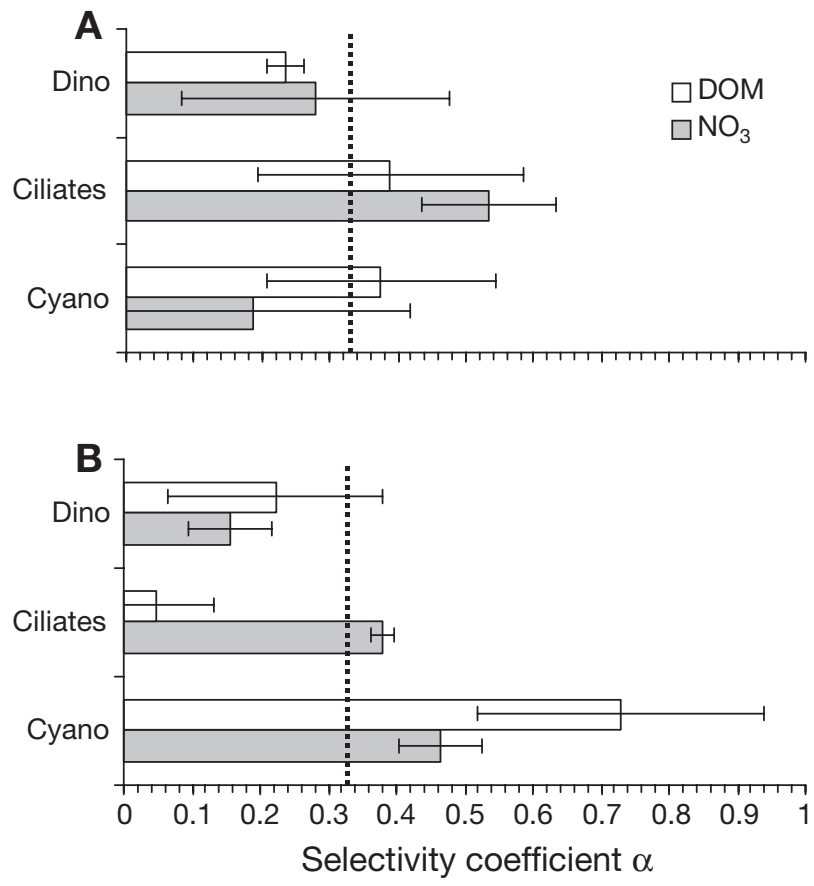

Fig. 5. Acartia bifilosa. Mean $( \pm \mathrm{SD})$ selectivity coefficient $(\alpha)$ when feeding on dinoflagellates (Dino), ciliates and cyanobacteria (Cyano) in the $\mathrm{NO}_{3}$ and DOM treatments during (A) Expt 1 and (B) Expt 2. Dotted line represents the $\alpha$-value when no selection occurs (0.33)

\section{Survival and reproduction}

Acartia bifilosa survival was highly variable, ranging from 0 to $92 \%$ (Table 2), and differed among treatments and experiments (2-way MANOVA; $\mathrm{p}<0.05)$. In addition, the interaction between these factors was significant (2-way MANOVA; $\mathrm{p}<0.05)$. Survival tended to decrease with increasing incubation time (24 and $72 \mathrm{~h}$ ) even if not significantly ( $t$-test; $\mathrm{p}>0.005$ ). It was lowest in Expt 3 (corresponding to Day 10) both at $24 \mathrm{~h}$ (2-way MANOVA; $\mathrm{p}<0.05)$ and $72 \mathrm{~h}$ (2-way MANOVA; $\mathrm{p}<0.01$ ), except for the $\mathrm{NO}_{3}$ treatment in which no difference was detected (Tukey's HSD; p > 0.05). In this last experiment, survival was highest in the $\mathrm{NO}_{3}$ treatment (Tukey's HSD; $\mathrm{p}<0.01 ; 71 \%$ ), whereas in the DOM and DOMFe treatments all females were dead after $72 \mathrm{~h}$ and very few were still alive in the $\mathrm{NO}_{3} \mathrm{Fe}$ treatment $(6 \%)$. Survival was negatively related to cyanobacterial biomass (Spearman correlation, $\mathrm{r}=-0.53 ; \mathrm{p}<0.001$ ) when considering the data from all treatments $\left(\mathrm{NO}_{3}, \mathrm{NO}_{3} \mathrm{Fe}, \mathrm{DOM}\right.$ and DOMFe) and experiments (1, 2 and 3).

EPR did not differ between consecutive days (24 and $48 \mathrm{~h}$ ) for any of the treatments or experiments ( $t$-test; $p>0.005)$. Therefore, average values for each treatment were calculated using both incubation days

Table 2. Acartia bifilosa. Mean (SD) egg production rate (EPR, egg female $\left.{ }^{-1} \mathrm{~d}^{-1}\right)$, egg-hatching success (EH, \%) and survival (SUR, \%) at 24 and $72 \mathrm{~h}$ for different treatments in Expts 1 (Days 1 to 3), 2 (Days 5 to 7 ) and 3 (Days 9 to 11). Results from Tukey's HSD test show treatments/experiments in increasing order. $=$ : no significant difference at $\mathrm{p}=0.05$; $<$ : significant difference at $\mathrm{p}=0.05$; groups that overlap are $\underline{\text { underlined. }}$. For treatment abbreviations see Fig. 1

\begin{tabular}{|c|c|c|c|c|c|}
\hline & $\mathrm{NO}_{3}$ & $\mathrm{NO}_{3} \mathrm{Fe}$ & DOM & DOMFe & Tukey's HSD \\
\hline \multicolumn{6}{|l|}{ Expt 1} \\
\hline EPR & $10(4)$ & $7(3)$ & $7(3)$ & $6(3)$ & $\mathrm{DOMFe}=\mathrm{NO}_{3} \mathrm{Fe}=\mathrm{DOM}=\mathrm{NO}_{3}$ \\
\hline $\mathrm{EH}$ & $62(25)$ & $50(0)$ & $56(18)$ & $34(9)$ & $\mathrm{DOMFe}=\mathrm{NO}_{3} \mathrm{Fe}=\mathrm{DOM}=\mathrm{NO}_{3}$ \\
\hline SUR $24 \mathrm{~h}$ & $77(25)$ & $82(3)$ & $72(9)$ & $79(9)$ & $\mathrm{DOM}=\mathrm{DOMFe}=\mathrm{NO}_{3}=\mathrm{NO}_{3} \mathrm{Fe}$ \\
\hline SUR $72 \mathrm{~h}$ & $55(48)$ & $64(12)$ & $54(6)$ & $61(18)$ & $\mathrm{DOM}=\mathrm{NO}_{3}=\mathrm{DOMFe}=\mathrm{NO}_{3} \mathrm{Fe}$ \\
\hline \multicolumn{6}{|l|}{ Expt 2} \\
\hline EPR & $7(3)$ & $5(2)$ & $5(2)$ & $3(1)$ & $\underline{\mathrm{DOMFe}} \mathrm{DOM} \mathrm{NO}_{3} \mathrm{Fe} \mathrm{NO}_{3}$ \\
\hline $\mathrm{EH}$ & $51(5)$ & $56(4)$ & $50(12)$ & $60(12)$ & $\overline{\mathrm{DOM}}=\overline{\mathrm{NO}_{3}=\mathrm{NO}_{3} \mathrm{Fe}}=\overline{\mathrm{DO}} \mathrm{MFe}$ \\
\hline SUR $24 \mathrm{~h}$ & $74(9)$ & $92(13)$ & $75(3)$ & $69(5)$ & $\mathrm{DOMFe}=\mathrm{NO}_{3}=\mathrm{DOM}=\mathrm{NO}_{3} \mathrm{Fe}$ \\
\hline SUR $72 \mathrm{~h}$ & $69(15)$ & $86(16)$ & $63(23)$ & $42(6)$ & $\mathrm{DOMFe}=\mathrm{DOM}=\mathrm{NO}_{3}=\mathrm{NO}_{3} \mathrm{Fe}$ \\
\hline \multicolumn{6}{|l|}{ Expt 3} \\
\hline EPR & $6(1)$ & 0 & 0 & 0 & $\mathrm{DOMFe}=\mathrm{DOM}=\mathrm{NO}_{3} \mathrm{Fe}<\mathrm{NO}_{3}$ \\
\hline $\mathrm{EH}$ & $26(9)$ & 0 & 0 & 0 & $\mathrm{DOMFe}=\mathrm{DOM}=\mathrm{NO}_{3} \mathrm{Fe}=\mathrm{NO}_{3}$ \\
\hline SUR $24 \mathrm{~h}$ & $73(13)$ & $55(9)$ & $40(32)$ & $24(27)$ & $\underline{\mathrm{DOMFe} \mathrm{DOM} \mathrm{NO}_{3} \mathrm{Fe}} \mathrm{NO}_{3}$ \\
\hline SUR $72 \mathrm{~h}$ & $71(5)$ & $6(6)$ & 0 & 0 & $\overline{\mathrm{DOMFe}}=\overline{\mathrm{DOM}}=\mathrm{NO}_{3} \mathrm{Fe}<\mathrm{NO}_{3}$ \\
\hline \multicolumn{6}{|c|}{ Tukey's HSD } \\
\hline EPR & $3=2=1$ & $3<2=1$ & $3<2=1$ & $3<2=1$ & \\
\hline $\mathrm{EH}$ & $3=2=1$ & $3<1=2$ & $3<2=1$ & $3<2=1$ & \\
\hline SUR $24 \mathrm{~h}$ & $3=2=1$ & $3=1=2$ & $3=1=2$ & 321 & \\
\hline SUR $72 \mathrm{~h}$ & $1=2=3$ & $3<1=2$ & $3<2=1$ & $3<2=1$ & \\
\hline
\end{tabular}


(Table 2). Overall, EPR was highest in the $\mathrm{NO}_{3}$ treatment (2-way ANOVA, Tukey's HSD; $\mathrm{p}<0.001$; up to 10 eggs female ${ }^{-1} \mathrm{~d}^{-1}$ ). Until the middle of the experiment (data from $\mathrm{NO}_{3}$ and DOM treatments, Expts 1 and 2), EPR was neither related to the ingestion rate of the different food groups nor to their proportions in TIR. However, there was a negative relationship between EPR and cyanobacterial biomass (Spearman correlation, $\mathrm{r}=-0.77$; $<<0.001$ ) when all treatments and the entire experimental time-course were considered. EPR was thus lowest in Expt 3 (2-way ANOVA; $\mathrm{p}<0.001$, Tukey's HSD; $\mathrm{p}<0.005$ ), except for the $\mathrm{NO}_{3}$ treatment in which no difference was found among experiments (Tukey's HSD; $\mathrm{p}>0.05$ ). In this last experiment, no eggs were produced in any other treatment $\left(\mathrm{NO}_{3} \mathrm{Fe}, \mathrm{DOM}\right.$ and DOMFe).

EH was lowest (2-way ANOVA, Tukey's HSD; p < $0.001)$ in Expt $3(26 \%)$, and was in general highest in the $\mathrm{NO}_{3}$ treatment and lowest in the DOMFe treatment (2-way ANOVA, Tukey's HSD; p < 0.05). As observed for the survival and EPR, cyanobacterial biomass was negatively associated with EH (Spearman correlation, $r=-0.53 ; p<0.001)$.

\section{DISCUSSION}

\section{Development of the microbial food web in DOM treatments: link to metazooplankton?}

Contrary to previous observations (e.g. Carlsson et al. 1995), DOM did not directly stimulate bacterial growth. Instead, bacterial development was coupled with phytoplankton biomass (linear regression; $\mathrm{p}<$ 0.001, irrespective of treatment), and cell-specific bacterial production did not differ among treatments (Stolte et al. 2006).

Marine bacteria seem to be better adapted to use dissolved organic nitrogen, DON (including high molecular weight DON) than are freshwater bacterioplankton (Stepanauskas et al. 1999). Stepanauskas et al. (1999) not only detected higher DON bioavailability, but also higher aminopeptidase activity by marine bacteria. Thus, we suggest that the low salinity (ca. 6 to $7 \%$ ) bacterial community in our study might have been unable to use DOM efficiently. Alternatively, DOM used in our experiments may have been mostly refractory to bacterial degradation. For instance, the high bioavailability of DON and DOP observed in the Baltic Sea by Stepanauskas et al. (2002) was due to a large contribution of organic matter from riverine algal-derived dissolved organic matter; in contrast, DOM seemed more resistant to bacterial degradation.

By the end of the experiment, heterotrophic nanoflagellates and ciliates were generally less numerous in all DOM treatments in which bacterial and cyanobacterial biomass accumulated. Metazooplankton was also much less abundant in the DOM treatments, even in the cylinders (DOMG) where $>100 \mu \mathrm{m}$ grazers were stocked. Therefore, our results could not confirm the hypothesis that a heterotrophic DOM-stimulated microbial food web would account for most metazooplankton development. In addition, DOM- and iron-stimulated cyanobacteria dominated regardless of whether grazers were added and subsequently depressed proto- and metazooplankton development (see below).

\section{Bottom-up control and allelopathic/inhibitory effect by cyanobacteria in $\mathrm{DOM}$ and $\mathrm{NO}_{3} \mathrm{Fe}$ cylinders}

\author{
Phytoplankton development
}

By the end of the experiment, cyanobacteria numerically dominated in all DOM tanks, and also dominated in tanks incubated with $\mathrm{NO}_{3} \mathrm{Fe}$ (which followed DOM tanks in terms of abundance) (Stolte et al. 2006). These were the treatments in which the biomass of other phytoplankton groups such as diatoms and dinoflagellates decreased greatly. We suggest that some negative allelopathic effect of cyanobacteria, possibly triggered by phosphate limitation (von Elert \& Jüttner 1997), may account for this response in our study. Phosphate depletion in the $\mathrm{NO}_{3} \mathrm{Fe}$ treatment and all DOM tanks after Day 8 (see Stolte et al. 2006) might have led to competition among phytoplankton. Under such circumstances, the production of allelopathic compounds by cyanobacteria may be a mechanism that improves competitive ability (von Elert \& Jüttner 1997).

\section{Proto- and metazooplankton development}

Low biomass of protozoans and metazooplankton in all DOM tanks and the $\mathrm{NO}_{3} \mathrm{Fe}$ treatment by the end of the experiment also seemed related to deleterious effects of the dominant cyanobacteria. In addition, the survival, EPR and EH of Acartia bifilosa measured in the bottle incubations were not only negatively related to cyanobacterial biomass, but were also extremely low in the $\mathrm{NO}_{3} \mathrm{Fe}, \mathrm{DOM}$ and DOMFe treatments by the end of the experiment, which supported the results obtained from the tanks.

We suggest that some inhibitory effect of cyanobacteria caused the high mortality of Acartia bifilosa recorded during the bottle incubations. Food-deprived females (kept in filtered seawater) had much higher survival (>70\%, data not shown) than those incubated 
with water from the $\mathrm{NO}_{3} \mathrm{Fe}$, DOM and DOMFe tanks. Nevertheless, during the first half of the experiment, A. bifilosa fed upon cyanobacteria, particularly the dominant Anabaena inaequalis, with no negative effect on survival and reproduction. Similarly, A. bifilosa can ingest the nodularin-producing Nodularia spumigena without any obvious negative effects on survival, even at a higher concentration of this cyanobacterium ( 460 $\mu \mathrm{g} \mathrm{C} \mathrm{l}^{-1}$, Koski et al. 2002; 1000 $\mu \mathrm{g} \mathrm{C}$ $\mathrm{l}^{-1}$, Kozlowsky-Suzuki et al. 2003) than used in the present study $\left(\sim 200 \mu \mathrm{g} \mathrm{C} \mathrm{l}^{-1}\right)$. Therefore, we suggest that the negative effect was likely due to extracellular compound(s) produced by the dominant cyanobacteria, rather than being a result of the ingestion of cyanobacterial cells containing intracellular toxins (e.g. nodularin produced by N. spumigena or some other cyanotoxin[s] produced by A. inaequalis). In addition, intracellular toxins might only negatively affect organisms capable of feeding on filamentous cyanobacteria, which are most likely to be larger metazooplankton (e.g. calanoid copepods), seldom protozoans. Decaying blooms of nodularin-producing $N$. spumigena may actually constitute a nutrient-rich substrate for the microbial food web (Engström-Öst et al. 2002) that sustains metazooplankton development (Koski et al. 2002).

Negative allelopathic activity is dependent on the concentration of the inhibitor (e.g. von Elert \& Jüttner 1997). Thus, the higher cyanobacterial biomass in all DOM tanks relative to the $\mathrm{NO}_{3} \mathrm{Fe}$ treatment may explain the lower biomass of proto- and metazooplankton in the former treatments. Such an effect was even more diluted in the other $\mathrm{NO}_{3}$ treatments, where cyanobacteria biomass was considerably lower and phosphate never became depleted (Stolte et al. 2006). Metazooplankton reproduced successfully and developed in those tanks. Accordingly, Acartia bifilosa reproduction and survival were sustained in the $\mathrm{NO}_{3}$ bottle incubations.

Although the toxic effects of intracellular phycotoxins on zooplankton have been largely investigated, the effects of extracellular compounds on potential grazers are relatively unknown. Immobilization of heterotrophic dinoflagellates caused by extracellular compound(s), rather than by saxitoxins produced by the dinoflagellate Alexandrium spp., was reported by Tillmann \& John (2002). Survival of the ciliate Euplotes affinis was affected by increasing densities of the haptophyte Prymnesium parvum added to a fixed concentration of Rhodomonas cf. baltica, especially when the former was grown under nutrient-limiting conditions (Granéli \& Johansson 2003). The negative effect was presumably due to some extracellular compound, because $P$. parvum was consistently avoided by the ciliate (Granéli \& Johansson 2003). Anabaena spp. may produce extracellular compounds that negatively affect survival, feeding activity and reproduction of some zooplankton (see Lampert 1987). Extracellular compounds produced by dinoflagellates (Huntley et al. 1986) or by the haptophyte Chrysochromulina polylepis (Nielsen et al. 1990) may also affect copepods. C. polylepis further inhibited the activity of bacteria and ciliates both in the field and in the laboratory (Nielsen et al. 1990). Nevertheless, filtrates from the cyanobacterium Anabaena affinis caused no toxic effect on Daphnia pulex, whereas suspensions containing filaments induced strong inhibition (Gilbert 1990). Thus, extracellular compounds produced by phytoplankton evoke species-specific responses in the same way as intracellular phycotoxins, and may affect organisms at different trophic levels (e.g. Nielsen et al. 1990).

\section{Trophic relations between metazooplankton and food types in $\mathrm{NO}_{3}$ cylinders}

Contrary to what was observed in all DOM and $\mathrm{NO}_{3} \mathrm{Fe}$ tanks, bacterioplankton had not accumulated in the $\mathrm{NO}_{3}$ and $\mathrm{NO}_{3} \mathrm{G}$ cylinders by the end of the experiment (Stolte et al. 2006). This indicates grazing pressure by bacterivores such as nanoflagellates, ciliates and nauplii (Laybourn-Parry 1992, Roff et al. 1995), which are in turn preyed upon by metazooplankton (Daan et al. 1988, Stoecker \& Capuzzo 1990).

Proto- and metazooplankton developed where availability of diatoms and dinoflagellates was high, but were unable to control phytoplankton development under the nutrient-enriched conditions (e.g. Olsson et al. 1992). However, by the end of the experiment, the biomass of Skeletonema costatum was significantly lower ( $t$-test; $\mathrm{p}<0.05)$ in the $\mathrm{NO}_{3} \mathrm{G}$ treatments than in the tanks receiving only $\mathrm{NO}_{3}$, which was indicative of grazing pressure. Species of the genus Acartia (Olsson et al. 1992) including A. clausi, in addition to Podon polyphemoides (Turner \& Granéli 1992), may for instance feed upon $S$. costatum.

The association of Acartia bifilosa and Centropages hamatus with large ciliates (displayed in Fig. 4) is consistent with their size preferences (e.g. Tiselius 1989, Koski et al. 2002) and supported by the bottle incubations, in which large ciliates were the food item most ingested by A. bifilosa. However, grazing pressure on large ciliates could not be inferred in the tanks because no significant difference was detected between $\mathrm{NO}_{3}$ and $\mathrm{NO}_{3} \mathrm{G}$ treatments.

Besides feeding on ciliates, Acartia bifilosa also fed on cyanobacteria and, to a lesser extent, on dinoflagellates. Unfortunately we could not estimate the feeding rates on Skeletonema costatum: by the time that most 
of the phytoplankton counts for the feeding experiments were finished, the majority of the diatom cells were no longer recognizable owing to the long preservation time. However, as discussed above, S. costatum likely contributed to the diet of $A$. bifilosa and of other metazooplankton because grazing impact on the diatom was detected in the $\mathrm{NO}_{3} \mathrm{G}$ tanks. Acartia spp. may sometimes also graze upon Synchaeta spp. (Stoecker \& Egloff 1987), and the higher abundance of rotifers (Mann-Whitney test; $\mathrm{p}<0.05$ ) in the $\mathrm{NO}_{3}$ tanks (compared with the $\mathrm{NO}_{3} \mathrm{G}$ tanks) by the end of the experiment could suggest either decreased predation (adult $A$. bifilosa population was not yet established in the $\mathrm{NO}_{3}$ tanks) or decreased competition with other metazooplankton (e.g. Gilbert 1990).

Acartia bifilosa egg production rates were in the range previously reported for the species (Schimdt et al. 1998, Koski et al. 2002), and did not improve with increased food concentration. At least until the middle of the experiment, increased feeding rates on ciliates, cyanobacteria or dinoflagellates did not affect EPR, indicating that the females were not limited by the amount of food. However, because cyanobacteria generally lack polyunsaturated fatty acids such as 20:5 $\omega 3$ and 22:603 (Brett \& Müller-Navarra 1997) that are essential for reproduction in crustaceans, and because ciliates do not necessarily improve copepod EPR (e.g. Ederington et al. 1995, but see Stoecker \& Egloff 1987), females could have been limited by the quality of the food. However, by the end of the experiment, EPR tended to decrease in the $\mathrm{NO}_{3}$ treatment, and no eggs were produced by the females in the $\mathrm{NO}_{3} \mathrm{Fe}$, DOM, DOMFe treatments. A similar trend was observed for egg hatching success, possibly caused by inhibitory compounds released by cyanobacteria (e.g. Koski et al. 1999). Cyanobacteria were the dominant food item in the $\mathrm{NO}_{3}$ and $\mathrm{NO}_{3} \mathrm{G}$ treatments, even though their biomass was much lower than in all DOM and $\mathrm{NO}_{3} \mathrm{Fe}$ tanks. Furthermore, other food types were available for zooplankton in the $\mathrm{NO}_{3}$ and $\mathrm{NO}_{3} \mathrm{G}$ tanks. Thus, possible deleterious effects of cyanobacteria were diminished, provided that other resources were available (e.g. Reinikainen et al. 1994). We cannot exclude the possibility of reduced hatching success due to some inhibitory compound released by Skeletonema costatum (Miralto et al. 1999), even if this diatom may contribute to positive secondary production by A. bifilosa (Schimdt et al. 1998).

\section{CONCLUSIONS}

Contrary to our hypothesis, DOM did not stimulate nanoflagellate, ciliate and metazooplankton development; on the contrary, their biomasses decreased greatly. Cyanobacteria dominated in the DOM and $\mathrm{NO}_{3} \mathrm{Fe}$ tanks in which other phytoplankton groups and proto- and metazooplankton were negatively affected. Our results suggest that, excluding cyanobacteria, the plankton development in all DOM and $\mathrm{NO}_{3} \mathrm{Fe}$ tanks was partly bottom-up controlled and was simultaneously affected by extracellular compounds produced by the dominant cyanobacteria, possibly triggered by phosphate limitation. The development of noncyanobacterial plankton was stimulated in the $\mathrm{NO}_{3}$ and $\mathrm{NO}_{3} \mathrm{G}$ treatments. In these treatments, the lower cyanobacterial biomass and the higher contribution of other food types likely decreased the negative effects of cyanobacteria on zooplankton. Thus, metazooplankton development and secondary production were sustained. Overall, our results suggest that increases in the input of DOM to the Baltic Sea can potentially stimulate cyanobacterial blooms that may disrupt the microbial food web and inhibit metazooplankton development.

Acknowledgements. We thank C. Legrand for help with phytoplankton identification, C. Esplund-Lindqvist and G. Wannhoff for laboratory assistance, U. Grandin, R. Johnson and J. Dahl for assistance and discussions on multivariate analysis, and G. Fistarol for discussions on allelopathy. This study was supported by MISTRA (Swedish Foundation for Strategic Environmental Research) and by the European Commission (Research Directorate General-Environment Programme-Marine Ecosystems) through the FATE project (grant holder E. Granéli, contract EVK3-2001-00050). B. Kozlowsky-Suzuki received a $\mathrm{PhD}$ grant from CNPq (The Brazilian National Council for Research). M. Karjalainen was financed by the Walter and Andrée de Nottbeck Foundation and the Maj and Tor Nessling Foundation. NorFA provided travel grants to M. Karjalainen and M. Koski during the experiments.

\section{LITERATURE CITED}

Balode M, Purina I, Béchemin C, Maestrini SY (1998) Effects of nutrient enrichment on the growth rates and community structure of summer phytoplankton from the Gulf of Riga, Baltic Sea. J Plankton Res 20:2251-2272

Brett MT, Müller-Navarra DC (1997) The role of highly unsaturated fatty acids in aquatic foodweb processes. Freshw Biol 38:483-499

Carlsson P, Granéli E, Tester P, Boni L (1995) Influences of riverine humic substances on bacteria, protozoa, phytoplankton, and copepods in a coastal plankton community. Mar Ecol Prog Ser 127:213-221

Chesson J (1978) Measuring preference in selective predation. Ecology 59:211-215

Daan R, Gonzalez SR, Klein Breteler WCM (1988) Cannibalism in omnivorous calanoid copepods. Mar Ecol Prog Ser 47:45-54

Daniel C, Gutseit K, Anésio AM, Granéli W (2005) Microbial food webs in the dark: independence of lake plankton from recent algal production. Aquat Microb Ecol 38:113-123

Ederington MC, McManus GB, Harvey HR (1995) Trophic transfer on fatty acids, sterols, and a triterpenoid alcohol 
between bacteria, a ciliate, and the copepod Acartia tonsa. Limnol Ocenanogr 40:860-867

Edler L (1979) Recommendations on methods for marine biological studies in the Baltic Sea. Phytoplankton and chlorophyll. Balt Mar Biologists 5:31-38

Engström-Öst J, Koski M, Schmidt K, Viitasalo M, Jónasdóttir SH, Kokkonen M, Repka S, Sivonen K (2002) Effects of toxic cyanobacteria on a plankton assemblage: community development during decay of Nodularia spumigena. Mar Ecol Prog Ser 232:1-14

Frost BW (1972) Effects of size and concentration of food particles on the feeding behaviour of the marine planktonic copepod Calanus pacificus. Limnol Oceanogr 17:805-815

Gilbert JJ (1990) Differential effects of Anabaena affinis on cladocerans and rotifers: mechanisms and implications. Ecology 71:1727-1740

Granéli E, Johansson N (2003) Effects of the toxic haptophyte Prymnesium parvum on the survival and feeding of a ciliate: the influence of different nutrient conditions. Mar Ecol Prog Ser 254:49-56

Hagström ̊̀, Azam F, Kuparinen J, Zweifel UL (2001) Pelagic plankton growth and resource limitations in the Baltic Sea. In: Wulff F, Rahm L, Larsson P (eds) A system analysis of the Baltic Sea. Ecological studies, Vol 148. Springer Verlag, Heidelberg, p 177-210

Hernroth L (1985) Recommendations on methods for marine biological studies in the Baltic Sea. Mesozooplankton biomass assessment. Balt Mar Biologists 10:1-32

Howarth RW, Marino R, Cole JJ (1988) Nitrogen fixation in freshwater, estuarine and marine ecosystems. 2. Biogeochemical controls. Limnol Oceanogr 33:688-701

Huntley M, Sykes P, Rohan S, Marin V (1986) Chemicallymediated rejection of dinoflagellate prey by the copepods Calanus pacificus and Paracalanus parvus: mechanism, occurrence and significance. Mar Ecol Prog Ser 28:105-120

Koski M, Engström J, Viitasalo M (1999) Reproduction and survival of the calanoid copepod Eurytemora affinis fed with toxic and non-toxic cyanobacteria. Mar Ecol Prog Ser 186:187-197

Koski M, Schmidt K, Engström-Öst J, Viitasalo M, Jónasdóttir SH, Repka S, Sivonen K (2002) Calanoid copepods feed and produce eggs in the presence of toxic cyanobacteria Nodularia spumigena. Limnol Oceanogr 47:878-885

Kozlowsky-Suzuki B, Karjalainen M, Lehtiniemi M, Engström-Öst J, Koski M, Carlsson P (2003) Feeding, reproduction and toxin accumulation by the copepods Acartia bifilosa and Eurytemora affinis in the presence of the toxic cyanobacterium Nodularia spumigena. Mar Ecol Prog Ser 249:237-249

Lampert W (1987) Laboratory studies on zooplankton-cyanobacteria interactions. NZ J Mar Freshw Res 21:483-490

Laybourn-Parry J (1992) Protozoan plankton ecology. Chapman \& Hall, New York

Miralto A, Barone G, Romano G, Poulet AS and 7 others (1999) The insidious effect of diatoms on copepod reproduction. Nature 402:173-176

Nielsen TG, Kiørboe T, Bjørnsen PK (1990) Effects of a Chrysochromulina polylepsis subsurface bloom on the planktonic community. Mar Ecol Prog Ser 62:21-35
Olsson P, Granéli E, Carlsson P, Abreu P (1992) Structuring of a postspring phytoplankton community by manipulation of trophic interactions. J Exp Mar Biol Ecol 158:249-266

Reinikainen M, Ketola M, Walls M (1994) Effects of the concentrations of toxic Microcystis aeruginosa and alternative food on the survival of Daphnia pulex. Limnol Oceanogr 39:424-432

Roff JC, Turner JT, Webber MK, Hopcroft RR (1995) Bacterivory by tropical copepod nauplii: extent and possible significance. Aquat Microb Ecol 9:165-175

Schmidt K, Kähler P, von Bodungen B (1998) Copepod egg production rates in the Pomeranian Bay (Southern Baltic Sea) as a function of phytoplankton abundance and taxonomic composition. Mar Ecol Prog Ser 174:183-195

Sherr EB, Sherr BF (1993) Preservation and storage of samples for enumeration of heterotrophic protists. In: Kemp PF, Sherr BF, Sherr EB, Cole JJ (eds) Handbook of methods in aquatic microbial ecology. Lewis Publishers, Boca Raton, FL, p 207-212

Sherr EB, Caron DA, Sherr BF (1993) Staining of heterotrophic protists for visualization via epifluorescence microscopy. In: Kemp PF, Sherr BF, Sherr EB, Cole JJ (eds) Handbook of methods in aquatic microbial ecology. Lewis Publishers, Boca Raton, FL, p 213-227

Stal LJ, Staal M, Villbrandt M (1999) Nutrient control of cyanobacterial blooms in the Baltic Sea. Aquat Microb Ecol 18:165-173

Stepanauskas R, Edling H, Tranvik LJ (1999) Differential dissolved organic nitrogen availability and bacterial aminopeptidase activity in limnic and marine waters. Microb Ecol 38:264-272

Stepanauskas R, Jørgensen NOG, Eigaard OR, Žvikas A, Tranvik LJ, Leonardson L (2002) Summer inputs of riverine nutrients to the Baltic Sea: bioavailability and eutrophication relevance. Ecol Monogr 72:579-597

Stoecker DK, Capuzzo JM (1990) Predation on Protozoa: its importance to zooplankton. J Plankton Res 12:891-908

Stoecker DK, Egloff DA (1987) Predation by Acartia tonsa Dana on planktonic ciliates and rotifers. J Exp Mar Biol Ecol 110:53-68

Stolte W, Balode M, Carlsson P, Grzebyk D and 5 others (2006) Stimulation of nitrogen-fixing cyanobacteria in a Baltic Sea plankton community by land-derived organic matter or iron addition. Mar Ecol Prog Ser 327:71-82

Tillman U, John U (2002) Toxic effects of Alexandrium spp. on heterotrophic dinoflagellates: an allelochemical defence mechanism independent of PSP-toxin content. Mar Ecol Prog Ser 230:47-58

Tiselius P (1989) Contribution of alloricate ciliates to the diet of Acartia clausi and Centropages hamatus in coastal waters. Mar Ecol Prog Ser 56:49-56

Turner JT, Granéli E (1992) Zooplankton feeding ecology: grazing during enclosure studies of phytoplankton blooms from the west coast of Sweden. J Exp Mar Biol Ecol 157: 19-31

von Elert E, Jüttner F (1997) Phosphorus limitation and not light controls the extracellular release of allelopathic compounds by Trichormus doliolum (Cyanobacteria). Limnol Oceanogr 42:1796-1802

Submitted: May 17, 2004; Accepted: October 2, 2006 Proofs received from author(s): April 19, 2007
Editorial responsibility: Otto Kinne (Editor-in-Chief), Oldendorf/Luhe, Germany 